\title{
PRE-SERVICE PRIMARY SCHOOL TEACHERS' OPINION ABOUT BOARD-GAMES IN DEVELOPING MENTAL COMPUTATION SKILLS
}

\author{
Iuliana Zsoldos-Marchis
}

\begin{abstract}
Mental computation skills are important not only in everyday life, but also for the development of different cognitive competencies. The most important period for the foundation of these skills are the early school years, thus primary school teachers have a decisive influence on this. Appropriate teaching methods for practicing mental computation have to be found and taught for future primary school teachers. One of these methods could be the use of board-games.

The aim of this paper is to present a study about pre-service primary school teachers' opinions on developing mental computation skills and the use of board-games for this purpose. Second year "Primary and preschool pedagogy" specialization students filled in a questionnaire developed by the researchers. Participants are from two different groups: Group 1 has experienced board-games for mental computation development during a mathematics course at the university, Group 2 hasn't used any board-games due to online teaching as covid restriction. The results show that preservice primary school teachers consider exercising mental computation important, with significantly higher mean in case of the Group 1. Most of them consider that mental computation skills have to be practiced for a few minutes on each mathematics lesson and games, especially didactical and board-games, can transform this practice into entertainment. Group 1 perceives a significantly higher importance level of using board-games for practicing mental computation. In the view of respondents, using board-games is an attractive teaching/learning method for pupils, which develops their cognitive competencies and social skills. The main disadvantage/obstacle in implementing board-game play in the classroom is that these games are considered timeconsuming. Class management problems could also be challenging when using board-games in a lesson. There are students who think that board-games don't have any disadvantage if they are correctly integrated into the lesson.
\end{abstract}

Keywords: pre-service primary school teachers, board-games, mental calculation skills

\section{Introduction}

Mental calculation skills are important not only in everyday life (Reys, Reys, Nohda, \& Emori, 1995), but also contribute to a deeper understanding of numbers (Reys, 1984; McIntosh, Reys, \& Reys, 1997; Verschaffel, Greer, \& De Corte, 2007), provide the foundation for the development of higher level thinking skills (Reys, 1984; Gusty, 2005), develop mathematical reasoning skills (Carvalho \& da Ponte, 2013), and problem solving skills (Lemonidis, 2016).

As the main purposes of teaching mathematics in primary school are developing number sense and problem solving skills, mental calculation has an important role in mathematics education for these group age.

Mental calculation skills have to be practiced frequently in order to obtain development, but the optimal number of intervention in order to get a significant development remains unknown (Ruiz \& Balbi, 2019). In Romania practicing mental calculation is part of almost every mathematics lesson in primary school, so the question is more on how to do it in order not to be boring for the pupils and to obtain good results. In primary school, different types of games are used for exercising mental computation, but mostly frontally played didactical games are implemented for this purpose. Board- 
games are the type of games which ensure intensive practicing, as it is played in small groups and every child perform many computations in a short time. Teachers like to use board-games in the classroom, and Mathematics is the subject with the most frequently used board-games, especially for exercising (Zsoldos-Marchis \& Juhász, 2020).

In this paper, we present a study about pre-service primary school teachers' opinion on developing mental computation skills and the use of board-games for this purpose.

\section{Theoretical background}

On a basic level, mental computation has been defined as the ability to calculate exact numerical answers without any aids (Reys, 1984). In many cases, when computing mentally an operation, students use algorithms for written calculation or use strategies very close to written algorithms (Baranyai, Egri, Molnár, \& Zsoldos-Marchis, 2019a). Mental calculation can be also defined as a higher order level skill, as "a set of procedures that allows a person to obtain a result by analyzing the numbers involved in the calculation without using a formal algorithm" (Parra, as cited in Ruiz \& Balbi, 2019, p. 318).

Number sense and mental calculation skills are highly interacting (Verschaffel, et. al, 2007; Heirdsfield, 2000). Mental calculation skills are even considered to be part of number sense in some theories (Lemonidis, 2016).

Mental computation skills have to be developed starting from early ages (Calvert, 1999; Blöte, Klein, \& Beishuizen, 2000). Teachers have an important role in pupils' mental computational skills development, they can impact in two ways this development: by their attitude towards mental computation and by the methods they use for practicing mental computation.

There are many studies about the role of the working memory in mental computation achievement (for example, Meyer, Salimpoor, Wu, Geary, \& Menon, 2010; Friso-van den Bos, van der Ven, Kroesbergen, \& van Luit, 2013). As mental computation supposes not to use paper-pencil, the role of working memory is important. When performing the mental computation intermediate results have to be kept in working memory. If the operation which has to be performed is not given in a printed form, this also has to be memorized. Usually, students perform higher in case when they get the operation printed than in case when they only hear it (Baranyai, Egri, Molnár, \& Zsoldos-Marchis, 2019b), and this can be explained by the extra use of the working memory. This memory can be developed by exercising mental computation. Also, by practicing calculations some results of operations are memorized, enter into the long/term memory, so the pupil can perform faster some mental computations. Thus, long-term memory also has an important role in mental computation, the pupils have to retrieve facts and strategies from it to perform the calculations (Heirdsfield, 2000).

Practicing mental calculation contributes not only to better computational skills and development of the working memory, but also to a positive attitude to mental computation (Mutawah, 2016). To change pupils' attitude the way of practicing mental calculation is also has an important impact.

Board-games can be used to practice mental calculation in a playful, fun environment. ZsoldosMarchis (2020) has developed some board-games for practicing mental computation. She found that if the theme of the game is interesting, students forget that they practice operations, they can embed their selves in the context of the game. The final goal of the game is also important, this give the conditions to win, so it is the main motivation for the student to play the game (Garris, Ahlers \& Driskell, 2002; Wilson, Bedwell, Lazarra, Salas, Burke, Estock, Orvis, \& Conkey, 2009). It is better that this final goal is connected to the story of the game, and not based only on acquisition of some points (ZsoldosMarchis, 2020). In order not to lose interest, the player needs to have some control over the game, not only be driven by luck (O'Connor \& Menaker, 2008; Wilson, et al., 2009). A way to insure this on board of the game instead of a single path a net of paths should be used. The player can decide in this way which path to choose to move from the starting point to the finishing point (Zsoldos-Marchis, 2020). Games "Amusement park" and "Magic castle" follow these principles. Also, the mental calculation is only an aid to archive the final goal in these games, not the goal of the game. 


\section{Research methodology}

\subsection{Research aim and questions}

The aim of the research is to study pre-service primary school teachers' opinions about developing mental computation skills and the use of board-games for this purpose.

The research questions are the following:

1. How important pre-service primary school teachers consider mental computation development?

2. How would pre-service primary school teachers implement mental computation practice?

3. Which advantages and disadvantages of using board-games in mathematics lessons pre-service primary school teachers see?

4. What is pre-service primary school teachers' opinion about the use of board-games in developing mental computation skills?

5. Are there differences between the opinion of the group of students who have experience with boardgames for developing mental computation skills and the group of students who didn't have experience with board-games during the mathematics course?

\subsection{Participants}

The participants of this survey research are 87 students in their second year of study in "Primary and preschool Pedagogy" specialization. All the participants are female, and their average age is 22.17 with mode 20 . Only $18.37 \%$ of them have teaching experience outside the teaching practicum during their university studies.

We have divided these participants in two groups (see Table 1):

- Students who have experienced exercising mental computation with board-games: They are students who in the university year 2018/2019 have participated in an intervention about the efficacy of different types of games in developing mental computation skills during the course "Mathematics in primary and preschool" (Baranyai, Egri, Molnár, \& Zsoldos-Marchis, 2019b). These students were in the experimental group who used board-games for practicing mental calculations. They have filled in the questionnaire at the end of the experimental period, in the second semester of the 2018/2019 university year.

- Students who have not experienced exercising mental computation with board-games: They are students who are studying the course "Mathematics in primary and preschool" in the first semester of the 2020/2021 university year, they have already had half of the courses taught, and because of the online teaching due to covid restrictions, they didn't have any chance to play board-games during these courses. They had some mental computation practice using some online individual games.

Table 1. Survey participants

\begin{tabular}{|l|l|c|c|c|}
\hline \multicolumn{1}{|c|}{ Group } & \multicolumn{1}{|c|}{ Description of the group } & $\begin{array}{c}\text { Number of } \\
\text { participants }\end{array}$ & $\begin{array}{c}\text { Average } \\
\text { age }\end{array}$ & $\begin{array}{c}\text { Mode } \\
\text { age }\end{array}$ \\
\hline Group 1 & $\begin{array}{l}\text { Students who have experienced } \\
\text { exercising mental computation with } \\
\text { board-games }\end{array}$ & 44 & 24.23 & 21 \\
\hline Group 2 & $\begin{array}{l}\text { Students who have not experienced } \\
\text { exercising mental computation with } \\
\text { board-games }\end{array}$ & 43 & 20.07 & 20 \\
\hline TOTAL & & 87 & 22.17 & 20 \\
\hline
\end{tabular}




\subsection{Research tool}

A questionnaire was developed with 4 demographical questions and 11 questions related with the topic of the research, from which 5 open questions and 6 closed questions (multiple-choice, scale, affirmations measured on a 5-level Likert scale). The Likert scale type questions contain 20 affirmations in total. The Cronbach's alpha of the questionnaire is 0.879 , which shows a good reliability.

\subsection{Data collection and analysis}

The questionnaire was distributed as a Google Drive Form to the participants at the beginning of the second semester during the 2018/2019 university year (Group 1) respectively in the middle of the first semester during the 2020/2021 university year (Group 2).

The closed questions were quantitatively analyzed using Microsoft Excel. In case of items measured on a 5-level scale percentages of choosing each variant from 1 to 5, mean and standard deviation was calculated. In case of items as affirmations where participants have to give their agreement level from 1 (I don't agree at all) to 5 (I totally agree), we have calculated the percentage of those doesn't agree (marked as No in tables) the affirmation adding the percentages of those choosing variant 1 and 2 and the percentage of those agree (marked as Yes in tables) the affirmation adding the percentages of those choosing variant 4 and 5 . The responses given by the students from the two studied groups were compared by a two-sample t-test. The open questions were qualitatively analyzed.

\section{Results and discussion}

\subsection{Importance of mental computation development}

Most of the respondents (93.11\%) consider that mental computation skills can be developed by practice $(\mathrm{M}=4.78, \mathrm{SD}=0.60$ on a 5-level scale). There is no statistically significant difference between Group $1(\mathrm{M}=4.86, \mathrm{SD}=0.18)$ and Group $2(\mathrm{M}=4.69, \mathrm{SD}=0.55)$, as $\mathrm{t}(85)=1.297, \mathrm{p}=$ 0.198 , but the average of the Group 1 is higher with 0.20 . Only few students (9.2\%) think that there are pupils whose mental computation skills can't be developed no matter how much we practice with them $(\mathrm{M}=2.07, \mathrm{SD}=1.03)$.

As regarding the importance of teaching mental computation in primary school, most of the participants $(97.7 \%)$ consider it very important $(\mathrm{M}=4.75, \mathrm{SD}=0.49)$. There is significant difference between the opinion of the students from Group $1(\mathrm{M}=4.86, \mathrm{SD}=0.12)$ and Group $2(\mathrm{M}=4.63, \mathrm{SD}$ $=0.33)$, as $\mathrm{t}(85)=2.311, \mathrm{p}=0.023$.

\subsection{Implementation of mental computation exercises}

Students were asked about their opinion on how often and how long mental computation practice should be included in a mathematics lesson (Figure 1). Most of the respondents (85.06\%) think that mental computation has to be practiced for a short time in every mathematics lesson. There is no significant difference between the responses given in Group $1(86.36 \%$ of them think that mental computation has to be practiced for a short time in every mathematics lesson) and Group 2 (83.72\% of them think that mental computation has to be practiced for a short time in every mathematics lesson).

Actually, a high percentage of students $(78.16 \%)$ consider that for the development of mental computation skills the number of interventions are more important than the length of them $(\mathrm{M}=4.17$, $\mathrm{SD}=0.913)$. There is a significant difference between Group $1(\mathrm{MD}=4.39, \mathrm{SD}=0.52)$ and Group 2 $(\mathrm{M}=3.95, \mathrm{SD}=1.09), \mathrm{t}(85)=2.251, \mathrm{p}=0.027$. 


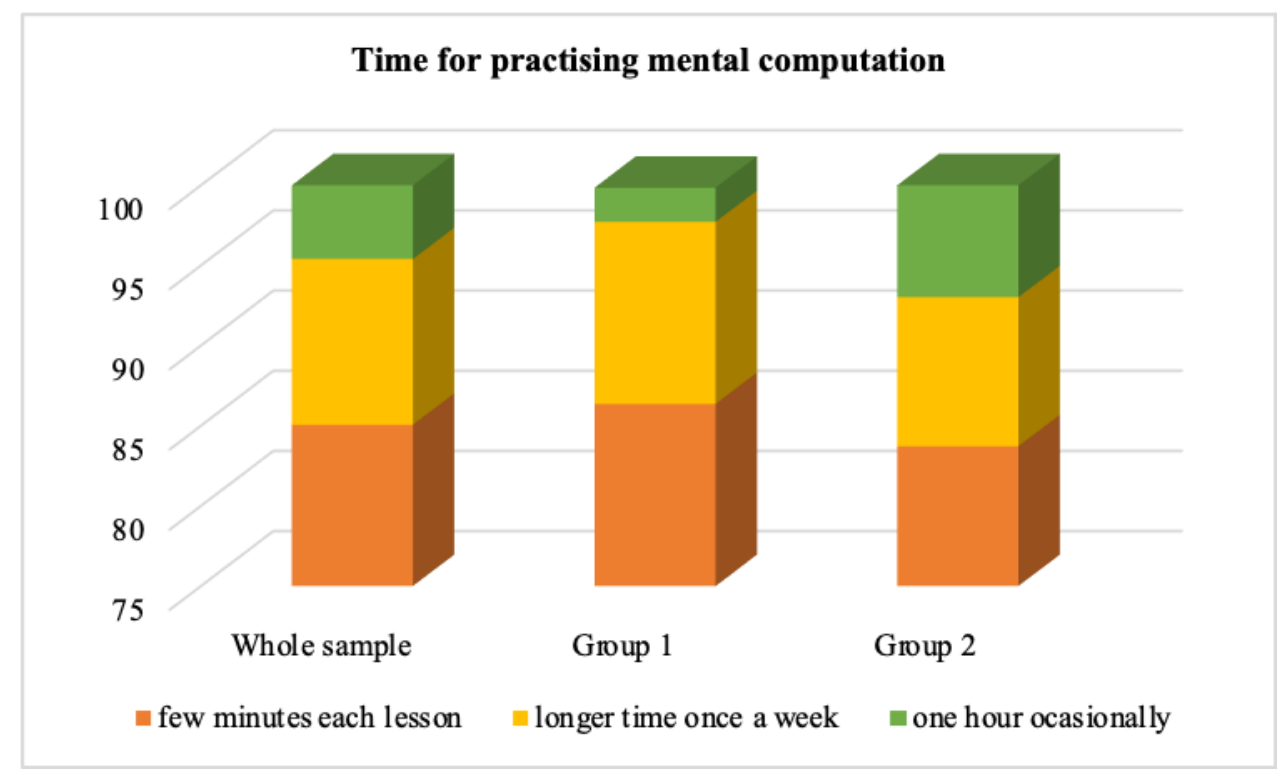

Figure 1. Time for practicing mental computation

Participants were asked to mark the importance of different types of games (didactical game, boardgame, mobile and computer game) on a 5-level scale. In case of each type of game the mean (M) and standard deviation (SD) for the whole sample, the mean and the standard deviation for Group 1 respectively for Group 2 are presented. A comparison between the means of the two groups was performed using two-sample t-test, the value of $\mathrm{p}$ and $\mathrm{t}$ are included in Table 2.

Table 2. Importance of different types of games in practicing mental computation

\begin{tabular}{|c|c|c|c|c|c|c|c|c|}
\hline \multirow{2}{*}{ Affirmation } & \multicolumn{2}{|c|}{$\begin{array}{c}\text { Whole } \\
\text { sample }\end{array}$} & \multicolumn{2}{|c|}{ Group1 } & \multicolumn{2}{|c|}{ Group 2} & \multirow{2}{*}{$\mathbf{p}$} & \multirow{2}{*}{$\mathbf{t}$} \\
\hline & $\mathbf{M}$ & SD & $\mathbf{M}$ & SD & $\mathbf{M}$ & SD & & \\
\hline Didactical game & 4.69 & 0.57 & 4.68 & 0.56 & 4.70 & 0.60 & 0.890 & -0.127 \\
\hline Board-games & 4.67 & 0.69 & 4.84 & 0.43 & 4.49 & 0.86 & 0.017 & 2.439 \\
\hline Mobile and computer game & 3.29 & 1.02 & 3.41 & 1.02 & 3.16 & 1.02 & 0.263 & 1.126 \\
\hline
\end{tabular}

Both didactical games $(\mathrm{M}=4.69, \mathrm{SD}=0.57)$ and board-games $(\mathrm{M}=4.67, \mathrm{SD}=0.69)$ are considered very important by the participants. In case of board-games the importance level perceived by Group 1 is significantly higher, than the level perceived by Group 2.

In Table 3 the affirmations related with the development of mental computation skills are presented. Participants have to mark on a scale from 1 (I don't agree at all) to 5 (I totally agree) their agreement with the given affirmations. In case of each affirmation the percentage of the students who don't agree (No), the percentage of students who agree (Yes), the mean (M) and standard deviation (SD) for the whole sample, the mean and the standard deviation for Group 1, respectively for Group 2 are presented. A comparison between the means of the two groups was performed using a two-sample ttest, the value of $\mathrm{p}$ and $\mathrm{t}$ are included in Table 3 . 
Table 3. Affirmations related with the development of mental computation skills

\begin{tabular}{|c|c|c|c|c|c|c|c|c|c|c|}
\hline \multirow{2}{*}{ Affirmation } & \multirow{2}{*}{ No } & \multirow{2}{*}{ Yes } & \multicolumn{2}{|c|}{$\begin{array}{c}\text { Whole } \\
\text { sample }\end{array}$} & \multicolumn{2}{|c|}{ Group1 } & \multicolumn{2}{|c|}{ Group 2} & \multirow{2}{*}{$\mathbf{p}$} & \multirow{2}{*}{$\mathbf{t}$} \\
\hline & & & $\mathbf{M}$ & SD & $\mathbf{M}$ & SD & $\mathbf{M}$ & SD & & \\
\hline $\begin{array}{l}\text { The most efficient method } \\
\text { for developing mental } \\
\text { computation skills is to } \\
\text { teach mental calculation } \\
\text { strategies. }\end{array}$ & 5.75 & 80.46 & 4.00 & 0.79 & 4.14 & 0.73 & 3.86 & 0.83 & 0.105 & 1.640 \\
\hline $\begin{array}{l}\text { For the development of } \\
\text { mental computation skills } \\
\text { the individual activities } \\
\text { are more efficient than the } \\
\text { group activities. }\end{array}$ & 18.39 & 49.43 & 3.54 & 1.13 & 3.39 & 1.17 & 3.70 & 1.22 & 0.204 & -1.279 \\
\hline $\begin{array}{l}\text { Mental computation } \\
\text { exercises are boring for } \\
\text { pupils. }\end{array}$ & 56.33 & 9.20 & 2.29 & 1.04 & 2.16 & 1.18 & 2.42 & 0.88 & 0.249 & -1.161 \\
\hline $\begin{array}{l}\text { Games make mental } \\
\text { computation exercises } \\
\text { entertaining. }\end{array}$ & 0 & 96.56 & 4.85 & 0.44 & 4.86 & 0.41 & 4.84 & 0.48 & 0.784 & 0.275 \\
\hline $\begin{array}{l}\text { The frontally performed } \\
\text { mental calculation } \\
\text { exercises develop only } \\
\text { students with better } \\
\text { mental computation skills. }\end{array}$ & 56.03 & 24.14 & 2.47 & 1.21 & 2.48 & 1.18 & 2.47 & 1.26 & 0.963 & 0.046 \\
\hline $\begin{array}{l}\text { The frontally performed } \\
\text { mental calculation } \\
\text { exercises are boring. }\end{array}$ & 58.62 & 17.24 & 2.38 & 1.13 & 2.30 & 1.17 & 2.47 & 1.10 & 0.488 & -0.696 \\
\hline $\begin{array}{l}\text { The best way to develop } \\
\text { mental computation skills } \\
\text { is by games. }\end{array}$ & 1.15 & 74.73 & 4.21 & 0.85 & 4.30 & 0.76 & 4.12 & 0.76 & 0.329 & 0.982 \\
\hline
\end{tabular}

The results show that almost all the respondents (96.56\%) agree that games make mental computation exercises entertaining, $80.46 \%$ of the participants think that teaching computation strategies is the most efficient way of developing mental computation skills and $74.73 \%$ consider that games are the best way for this. Only $9.20 \%$ of the respondents think that mental calculation exercises are boring for pupils, and $17.24 \%$ that the frontally performed mental calculation exercises are boring. Half of the students consider that individual activities are more efficient than group activities for developing mental computation skills. There is no significant difference between the responses of the two groups in case of any affirmations from Table 3.

\subsection{Advantages and disadvantages of using board-games in mathematics lessons}

\subsubsection{Advantages of using board-games in mathematics lessons}

The item related with the advantages of board-games in mathematics education was an open question. Reading the responses, the keywords related with the appeared advantages were taken out from the text, in case of each advantage the number of occurrences was noted. These keywords then were grouped into three categories: Attractiveness of the method, Development of cognitive competencies, and Development of social skills. Table 4 contains the obtained data. We included in this table only 
those keywords which were mentioned by more than one student, and the keywords given by only one student was grouped under the word "other".

Table 4. Advantages of using board-games in mathematics lessons

\begin{tabular}{|c|c|c|c|c|c|c|c|}
\hline \multirow{2}{*}{ Category } & \multirow{2}{*}{$\begin{array}{l}\text { Examples of } \\
\text { keyword }\end{array}$} & \multicolumn{3}{|c|}{$\begin{array}{c}\text { Number of occurrence of each } \\
\text { keyword }\end{array}$} & \multicolumn{3}{|c|}{$\begin{array}{l}\text { Number of occurrence of } \\
\text { keywords per category }\end{array}$} \\
\hline & & Group 1 & Group 2 & Total & Group 1 & Group 2 & Total \\
\hline \multirow{5}{*}{$\begin{array}{l}\text { Attractiveness of the } \\
\text { method }\end{array}$} & $\begin{array}{l}\text { Learning while } \\
\text { play }\end{array}$ & 25 & 14 & 39 & \multirow{5}{*}{35} & \multirow{5}{*}{37} & \multirow{5}{*}{72} \\
\hline & Interesting & 3 & 14 & 17 & & & \\
\hline & Positive attitude & 3 & 0 & 3 & & & \\
\hline & Motivation & 4 & 2 & 6 & & & \\
\hline & other & 0 & 7 & 7 & & & \\
\hline \multirow{6}{*}{$\begin{array}{l}\text { Developing } \\
\text { cognitive skills }\end{array}$} & Logical thinking & 9 & 1 & 10 & \multirow{6}{*}{17} & \multirow{6}{*}{18} & \multirow{6}{*}{35} \\
\hline & $\begin{array}{l}\text { Strategical } \\
\text { thinking }\end{array}$ & 4 & 1 & 5 & & & \\
\hline & Problem solving & 3 & 2 & 5 & & & \\
\hline & Concentration & 1 & 3 & 4 & & & \\
\hline & Creativity & 0 & 3 & 3 & & & \\
\hline & other & 0 & 8 & 8 & & & \\
\hline \multirow{6}{*}{$\begin{array}{l}\text { Developing social } \\
\text { skills }\end{array}$} & $\begin{array}{l}\text { Working in } \\
\text { groups }\end{array}$ & 7 & 8 & 15 & \multirow{6}{*}{22} & \multirow{6}{*}{19} & \multirow{6}{*}{41} \\
\hline & Following rules & 4 & 3 & 7 & & & \\
\hline & $\begin{array}{l}\text { Learning how to } \\
\text { win/lose }\end{array}$ & 2 & 1 & 3 & & & \\
\hline & $\begin{array}{l}\text { Listening to each } \\
\text { other }\end{array}$ & 2 & 0 & 2 & & & \\
\hline & Patience & 1 & 1 & 2 & & & \\
\hline & other & 6 & 6 & 12 & & & \\
\hline
\end{tabular}

We could observe that the richest category is the Attractiveness of the method. Many respondents think that with a board-game pupils learn while feeling that they play, so "they learn without noticing". The use of board-game is attractive, fun, and exciting to pupils, insures interactivity and active participation, increases motivation for learning.

In case of the Developing cognitive skills category, the respondents think that besides learning mathematical notions and exercising mental computation, pupils also develop different cognitive competencies as logical and strategical thinking, decision taking skill, attention, concentration, 
creativity. Playing the board-games in groups pupils see how their classmates think in case of a problem/operation/situation, they learn thinking/solving strategies from each other. The higher achieving students from a group can help lower achieving students, which contribute to a better understanding of mathematical notions, rules, and solving methods.

As regarding the Developing social skills category, research participants consider that by playing board-games pupils learn how to work in groups, how to cooperate with others, listen to each other. Pupils experiment on how to follow rules, they become aware of the necessity of rules. They learn how to win and how to use, how to overcome the frustration of a defeat. Also, they learn that making mistakes is part of the learning process, so making an error in a round of the game can encourage pupils to be more attentive in the next round. Losing a game because lack of knowledge or competencies can encourage pupils to learn, exercise more to be able to win the next game.

We observed that there is no significant difference between the number of advantages enumerated by Group 1 and Group 2.

\subsubsection{Disadvantages of using board-games in mathematics lessons}

The item related with the disadvantages of board-games in mathematics education was an open question. Reading the responses, the keywords related with the appeared disadvantages were taken out from the text, in case of each disadvantage the number of occurrences was noted. These keywords then were groups in three categories: Time management, Class management, and Games needed. Table 5 contains the obtained data. We included in this table only those keywords which were mentioned by more than one student, and the keywords given by only one student was grouped under the word "other".

Table 5. Disadvantages of using board-games in mathematics lessons

\begin{tabular}{|c|c|c|c|c|c|c|c|}
\hline \multirow{2}{*}{ Category } & \multirow{2}{*}{$\begin{array}{l}\text { Examples of } \\
\text { keyword }\end{array}$} & \multicolumn{3}{|c|}{$\begin{array}{c}\text { Number of occurrence of each } \\
\text { keyword }\end{array}$} & \multicolumn{3}{|c|}{$\begin{array}{l}\text { Number of occurrence of } \\
\text { keywords per category }\end{array}$} \\
\hline & & Group 1 & Group 2 & Total & Group 1 & Group 2 & Total \\
\hline \multirow[b]{2}{*}{ Time management } & Too much time & 17 & 17 & 34 & \multirow[b]{2}{*}{25} & \multirow[b]{2}{*}{26} & \multirow[b]{2}{*}{51} \\
\hline & $\begin{array}{l}\text { Difficult to } \\
\text { organize time }\end{array}$ & 8 & 9 & 17 & & & \\
\hline \multirow{6}{*}{ Class management } & $\begin{array}{l}\text { Conflicts between } \\
\text { pupils }\end{array}$ & 6 & 8 & 14 & \multirow{6}{*}{15} & \multirow{6}{*}{18} & \multirow{6}{*}{33} \\
\hline & $\begin{array}{c}\text { There are pupils } \\
\text { who don't want to } \\
\text { play }\end{array}$ & 4 & 2 & 6 & & & \\
\hline & $\begin{array}{l}\text { Upset the class } \\
\text { order, noisy }\end{array}$ & 3 & 1 & 4 & & & \\
\hline & $\begin{array}{c}\text { Not all the pupils } \\
\text { participate } \\
\text { actively }\end{array}$ & 1 & 2 & 3 & & & \\
\hline & $\begin{array}{c}\text { Difficulty in } \\
\text { integrating in the } \\
\text { lesson }\end{array}$ & 0 & 3 & 3 & & & \\
\hline & $\begin{array}{c}\text { Difficulty in } \\
\text { checking group's }\end{array}$ & 0 & 2 & 2 & & & \\
\hline
\end{tabular}




\begin{tabular}{|c|c|c|c|c|c|c|c|}
\hline & work & & & & & & \\
\hline & other & 1 & 0 & 1 & & & \\
\hline \multirow{2}{*}{ Games needed } & Number of games & 4 & 1 & 5 & \multirow{2}{*}{6} & \multirow{2}{*}{1} & \multirow{2}{*}{7} \\
\hline & Price & 2 & 0 & 2 & & & \\
\hline
\end{tabular}

We can observe in Table 5, that the main disadvantage seen by the respondents is related with Time management. Issues with time consumption and time management are usually mentioned between the obstacles of using board-games in the classroom (Crews, 2011). The participants of this research consider that board-games are time-consuming, some of the games are too long to be integrated into a lesson, and it is unpredictable how long a group plays a certain game. Time seems to be the main obstacle of integrating games - in general (Avdiu, 2019; Zsoldos-Marchis \& Hari, 2020), respectively board-games - in particular (Crews, 2011; Zsoldos-Marchis \& Juhász, 2020) in lessons.

From the class management point of view, some respondents found it difficult to plan the lesson in a way to overcome upsetting class order, to prevent conflicts in the groups, to actively involve every pupil. The teacher can't check the work of every group, of every pupil individually, so the verification of the responses and solutions are the duty of the pupils who play together in a group. In this way could happen that a wrong solution is accepted by the group. In order to prevent conflicts in the groups, some respondents proposed the use of cooperative games instead of competitive ones. There is another aspect related with class management the organization of the groups. Could happen, that there are pupils who rarely or never win a game, as there are high achieving pupils in their group, so they lose interest and motivation.

We observed that there is no significant difference between the number of disadvantages enumerated by Group 1 and Group 2.

\subsection{Using board-games for mental computation exercises}

In Table 6 the affirmations related with the use of board-games for the development of mental computation skills are presented. Participants have to mark on a scale from 1 (I don't agree at all) to 5 (I totally agree) their agreement with the given affirmations. In case of each affirmation the percentage of the students who don't agree (No), the percentage of students who agree (Yes), the mean (M) and standard deviation (SD) for the whole sample, the mean and the standard deviation for Group 1 , respectively for Group 2 are presented. A comparison between the means of the two groups was performed using a two-sample $\mathrm{t}$-test, the value of $\mathrm{p}$ and $\mathrm{t}$ are included in Table 6 .

Table 6. Affirmations related with the use of board-games for mental computation exercises

\begin{tabular}{|c|c|c|c|c|c|c|c|c|c|c|}
\hline \multirow{2}{*}{ Affirmation } & \multirow{2}{*}{$\begin{array}{l}\text { No } \\
(\%)\end{array}$} & \multirow{2}{*}{$\begin{array}{l}\text { Yes } \\
(\%)\end{array}$} & \multicolumn{2}{|c|}{$\begin{array}{l}\text { Whole } \\
\text { sample }\end{array}$} & \multicolumn{2}{|c|}{ Group1 } & \multicolumn{2}{|c|}{ Group 2} & \multirow{2}{*}{$\mathbf{p}$} & \multirow{2}{*}{$\mathbf{t}$} \\
\hline & & & $\mathbf{M}$ & SD & $\mathbf{M}$ & SD & $\mathbf{M}$ & SD & & \\
\hline $\begin{array}{l}\text { Board-games can greatly } \\
\text { improve mental } \\
\text { computation skills. }\end{array}$ & 2.30 & 88.51 & 4.00 & 0.79 & 4.14 & 0.73 & 3.86 & 0.83 & 0.105 & 1.640 \\
\hline $\begin{array}{l}\text { I will use board-games in } \\
\text { mathematics lessons. }\end{array}$ & 1.15 & 89.65 & 4.49 & 0.76 & 4.75 & 0.53 & 4.23 & 0.87 & 0.001 & 3.357 \\
\hline $\begin{array}{l}\text { It is easy to design a } \\
\text { mathematical board-game. }\end{array}$ & 42.53 & 21.84 & 4.67 & 0.69 & 4.84 & 0.48 & 4.49 & 0.83 & 0.017 & 2.439 \\
\hline $\begin{array}{l}\text { From the benefits/time- } \\
\text { consuming point of view }\end{array}$ & 79.31 & 5.75 & 2.78 & 1.02 & 2.86 & 0.83 & 2.70 & 1.21 & 0.100 & -1.661 \\
\hline
\end{tabular}




\begin{tabular}{|l|l|l|l|l|l|l|l|l|l|l|}
\hline $\begin{array}{l}\text { is not effective to develop } \\
\text { mathematical } \\
\text { competencies with board- } \\
\text { games. }\end{array}$ & & & & & & & & & & \\
\hline $\begin{array}{l}\text { The paper-based board- } \\
\text { games are more attractive } \\
\text { to pupils than digital ones. }\end{array}$ & 37.93 & 31.03 & 3.02 & 1.29 & 3.16 & 1.16 & 2.88 & 1.42 & 0.324 & 0.992 \\
\hline $\begin{array}{l}\text { I know digital board- } \\
\text { games. }\end{array}$ & 24.13 & 60.92 & 3.70 & 1.46 & 3.59 & 1.47 & 3.81 & 1.47 & 0.481 & -0.709 \\
\hline $\begin{array}{l}\text { Board-games consume too } \\
\text { much time from a } \\
\text { mathematics lesson. }\end{array}$ & 50.58 & 14.94 & 2.41 & 1.07 & 2.16 & 0.99 & 2.67 & 1.11 & 0.024 & -2.293 \\
\hline $\begin{array}{l}\text { With the use of board- } \\
\text { games the lesson is more } \\
\text { interesting for pupils. }\end{array}$ & 1.15 & 94.25 & 4.84 & 0.54 & 4.95 & 0.30 & 4.72 & 0.70 & 0.046 & 2.027 \\
\hline
\end{tabular}

Most of the participants agree that with the use of board-games the lesson is more interesting for pupils $(94.25 \%)$, they will use board-games in mathematics lessons $(89.65 \%)$, and they think that board-games can greatly improve mental computation skills $(88.51 \%)$. The comparison of the two groups shows that the intension to use board-games in mathematics lessons of the students from Group 1 is significantly stronger than in case of students from Group 2. Also, students from Group 1 consider significantly more interesting for pupils the use of board-games than students from Group 2.

Only $5.75 \%$ of the students consider that from the benefits/time-consuming point of view is not effective to develop mathematical competencies with board-games, and $14.94 \%$ of the respondents think that board-games consume too much time from a mathematics lesson. These percentages are significantly lower than those obtained for in-service primary school teachers by Zsoldos-Marchis and Juhász (2020), in which study $33.3 \%$ of the participants consider board-games time-consuming and $69.3 \%$ perceive difficulty in managing time during the lesson if using a board-game. Comparing the opinion of the two groups, students from Group 1 consider board-games significantly less timeconsuming than students from Group 2, which shows that the experience with playing board-games during a mathematics curse could change the attitude towards board-games.

Only $31.03 \%$ of the respondents consider that paper-based board-games are more attractive to primary school pupils, and there is no significant difference between the opinions of the two groups. In Group 1 during the experiment for developing mental-calculation skills only paper-based board-games were used, so the hypothesis was that they would have a more positive attitude towards paper-based boardgames. Another issue with this affirmation is that some students consider any digital game where mental computations have to be performed as board-game. Thus, the quite high percentage $(60 \%)$ of the students who affirmed that she knows a digital board-game is not real, as the examples they gave are more one-player digital games. Even in case of in-service primary school teachers, the definition of board-game is not clear for all of them (Zsoldos-Marchis \& Juhász, 2020).

\section{Conclusions}

The results presented in this paper show that pre-service primary school teachers consider exercising mental computation important and consider mental computation skills developable by practice. They think that mental computation skills have to be practiced for a few minutes on each mathematics lesson and games, especially didactical and board-games, can transform this practice in entertainment.

The participants consider that using board-games in mathematics lessons is an attractive teaching/learning method for pupils, which develops their cognitive competencies and social skills. The main disadvantage/obstacle in implementing board-game play in the classroom is that these games are considered time-consuming. Class management problems could also be challenging when 
using board-games in a lesson. There are students who think that board-games don't have any disadvantage if they are correctly integrated into the lesson.

Comparing the results given by Group 1 and Group 2, Group 1 perceives a significantly higher importance level for developing mental computation skills and they are more convinced that for the development of mental computation skills the number of interventions are more important than the length of them. Students from Group 1 are also perceived a significantly higher importance level of using board-games for practicing mental computation and they have stronger intent to use boardgames in mathematics lessons. They consider board-games significantly more interesting for pupils and significantly less time-consuming.

This survey research not only explored pre-service primary school teachers' opinion about developing mental computation skills with board-games, but also have shown that students' experience with board-games for mental computation development has changed their attitude towards using boardgames.

\section{Bibliography}

Avdiu, E. (2019). Game-Based Learning Practices in Austrian Elementary Schools. Educational Process: International Journal, 8(3), 196-206.

Baranyai T., Egri E., Molnar A. E., \& Zsoldos-Marchis I. (2019a). Mental calculation strategies used by pre-service primary school teachers, Proceedings of the 11th International Conference on Education and New Learning Technologies, 8717 - 8724 , https://doi.org/10.21125/edulearn.2019.2167

Baranyai T., Egri E., Molnar A. E., \& Zsoldos-Marchis I. (2019b). Developing Preservice Primary School Teachers' Mental Computation Competency by Games, Acta Didactica Napocensia, 12(1), 153 - 164, https://doi.org/10.24193/adn.12.1.11.

Blöte, A. W., Klein, A. S., \& Beishuizen, M. (2000). Mental computation and conceptual understanding. Learning and Instruction, 10, 221-247.

Carvalho, R., \& da Ponte, J. P. (2013). Student's mental computation strategies with rational numbers represented as fractions. In Ubuz, B., Haser, Ç., \& Mariotti, M. A. (Eds.), Proceedings of the Eighth Congress of the European Society for Research in Mathematics Education (283-292). Ankara: Middle East Technical University.

Crews, A. (2011). Using games to support the curriculum: getting teachers on $\langle\langle$ board $\rangle>$, Knowledge Quest, 40(1), 10-13.

Friso-van den Bos, I., van der Ven, S. H. G., Kroesbergen, E. H., and van Luit, J. E. H. (2013). Working memory and mathematics in primary school children: a meta-analysis. Educational Research Review 10, 29-44. https://doi.org/10.1016/j.edurev.2013.05.003

Garris, R., Ahlers, R., \& Driskell, J. E. (2002). Games, motivation, and learning: A research and practice model. Simulation \& Gaming, 33(4), 441-467.

Gusty, R. (2005). The importance of mental calculation skills: a review of the literature. Thesis. Rochester Institute of Technology. Accessed from https://scholarworks.rit.edu/theses/4018/ [October 2020]

Heirdsfield, A. (2000). Mental computation: Is it more than mental architecture? Presented at the Annual Meeting of Australian Association for Research in Education, December 2000.

Lemonidis, C. (2016). Mental computation and estimation: Implications for mathematics, education research, teaching and learning. Oxon: Routledge.

McIntosh, A., Reys, B., \& Reys, R. (1992). A proposed framework for examining basic number sense. For the Learning of Mathematics, 12, 2-8.

Meyer, M. L., Salimpoor, V. N., Wu, S. S., Geary, D. C., \& Menon, V. (2010). Differential contribution of specific working memory components to mathematics achievement in 2nd and 3rd 
graders. Learning and Individual Differences, 20, 101-109. https://doi.org/10.1016/j.lindif. 2009.08.004

Mutawah, M. A. A. (2016). The Effect of Practicing Mental Calculation Strategies on Teacher Candidates' Numeracy Proficiency. International Journal of Education \& Literacy Studies, 4(2), 1-12.

O'Connor, D. L., \& Menaker, E. S. (2008). Can Massively Multiplayer Online Gaming Environments Support Team Training? Performance Improvement Quarterly, 21(3), 23-41.

Reys, R.E. (1984). Mental computation and estimation: Past, present and future. Elementary School Journal, 84 (5), 546-557.

Reys, R. E., Reys, B. J., Nohda, N., \& Emori, H. (1995). Mental computation performance and strategy use of Japanese students in grades 2, 4, 6, and 8. Journal for Research in Mathematics Education, 26, 304-326. DOI: 10.2307/749477.

Ruiz, C. \& Balbi, A. (2019). The effects of teaching mental calculation in the development of mathematical abilities. The Journal of Educational Research, 112(3), 315326, https://doi.org/10.1080/00220671.2018.1519689

Verschaffel, L., Greer, B. \& De Corte, E. (2007). Whole number concepts and operations. In: Lester, F. K. (Ed.). Second handbook of research on mathematics teaching and learning (pp. 557- 628). Greenwich, CT: Information Age Publishing.

Wilson, K. A., Bedwell, W. L., Lazarra, E. H., Salas, E., Burke, C. S., Estock, J. L., Orvis, K. L. \& Conkey, C. (2009). Relationships between Game Attributes and Learning Outcomes. Simulation \& Gaming, 40(2), 217-266.

Zsoldos-Marchis I. (2019). Designing board-games for developing pre-service primary school teachers' mental calculation skills, Proceedings of 11th International Conference on Education and New Learning Technologies, 7757 - 7765, https://doi.org/10.21125/edulearn.2019.1880.

Zsoldos-Marchis I., Hari T. H. (2020). Game based learning (GBL) in primary schools from Romania, Proceedings of the 12th International Conference on Education and New Learning Technologies, 7255-7260, https://doi.org/10.21125/edulearn.2020.1863

Zsoldos-Marchis I., Juhász A. (2020). Board-games in the primary classroom: teachers practice and opinion, Proceedings of 14th International Technology Education and Development Conference, 7573 - 7582, https://doi.org/10.21125/inted.2020.2041

\section{Author}

Iuliana Zsoldos-Marchis, Babeș-Bolyai University, Cluj-Napoca (Romania). E-mail: iuliana.marchis@ubbcluj.ro

\section{Acknowledgement}

The author is grateful to Andrea-Éva Molnár for her ideas in developing the questionnaire used in this research. Many thanks also to the students who have participated in this research. 